\title{
IMPACTS OF SAND AND GRAVEL QUARRYING ON THE STREAM CHANNEL AND SURROUNDing ENVIRONMENT
}

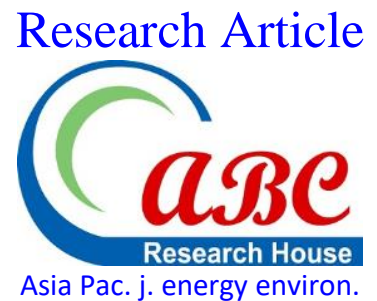

\author{
Maharabam Anjali Devi ${ }^{1}$, Lunghim Rongmei ${ }^{2}$ \\ ${ }^{1}$ M.A Student, Geography Department, Manipur University, Imphal, Manipur 795003, INDIA \\ ${ }^{2}$ Cartographer, Geography Department, Manipur University, Imphal, Manipur 795003, INDIA \\ *Email for Correspondence: lunghimrongmei@yahoo.in
}

Abstract

The longtime sustainability of river channel in the natural process depends on the gradient, volume of water, sediment supply and deposition in the river. Naturally, rivers maintain balance of river channel in all stage of the cycle of erosion. However, human activity mainly sand and gravel mining frequently disturb the balance that has much impact on the river morphology. The Imphal River between Motbung to Awang Leikinthabi is one of the worse sand and gravel-querying regions in Manipur. Hence, the main aim of this paper is to assess the impacts of querying on riverine landform and surrounding environment by using Remote Sensing and GIS.

Key words

River channel, cycle of erosion, river morphology, riverine landform, Remote Sensing and GIS

This article is is licensed under a Creative Commons Attribution-NonCommercial 4.0 International License.

Attribution-NonCommercial (CC BY-NC) license lets others remix, tweak, and build upon work non-commercially, and although the new works must also

acknowledge \& be non-commercial.

\section{INTRODUCTION}

For thousands of years, man has been using sand and gravel for constructing roads, dams, buildings etc.(The Ojos Negros Research Group, 2008). 'Sand and gravel are components of soil which takes years to be formed but extracted in a matter of days. Sand and gravels are underground geological resources formed from eroding mountain rocks carried by streams and rivers (Tariro Madyise, 2013)'. Sand and gravel are obtaining directly from the river channel, flood plain and adjacent river terrace through the process of quarrying. Quarrying has defined as an activity where sands and gravels are excavating for constructing building and making roads. According to Langer (2003), Sand and gravel, mining refers to the actual process of removal of sand or gravel from place of their occurrence.

Quarrying activities is a huge strategy for local economic development by creating jobs and creating new habitats for the people. 'According to Draggan (2008), sand and gravel are crucial resources to economic development activities in developed and developing nations.' However, increasing demand of sand and gravel leads to excessive extraction within a few years causing long-term environmental negative impact. 'Impacts of sand mining and gravel extraction can be classified into three categories as presented by Stebbins (2006). There are physical impacts that are a result of mining from streambed causing alteration of channel slope and changes in channel morphology. Sand quarrying and dredging activities, reducing water quality of downstream and increase treatment costs. Ecological impacts such as loss of habitats and species disturbance are a result of mining gravel and sand continuously leading to removal of channel substrate, suspension of sediments and clearance of vegetation.' In this era of rapid spatial development, people have turned river and flood plains as a major source of sand and gravel for construction purposes. Sand and gravel quarrying is carried out along the Imphal River for more than 20 years. Now the river is widely exploited due to excessive sand and gravel extraction to meet the increasing demand of the people, and it has adversely affects the surrounding environment of the river. Hence, the theme of this paper is to identify the environmental impact by the ongoing quarrying activities along the Imphal River and compare the socio-economic benefit that provides to the people who are engaged in quarrying activities.

\section{StUdy AREA}

The study area covers the Imphal River located at a distance of $20 \mathrm{~km}$ north of Imphal, capital of Manipur. The study area covers $26 \mathrm{~km}^{2}$ and the length of the river within the study area covers $11 \mathrm{~km}$. In addition, its geographical position extends from $24^{0} 57^{\prime}$ north to $24^{0} 54^{\prime}$ north and from $93^{0} 51^{\prime}$ east to $93^{0} 54^{\prime}$ east and with an elevation of 2745 feet above mean sea level. Imphal River originates from the hill ranges of the Senapati District and flow southward. The river is a great source of sand and gravel that is widely exploited. 


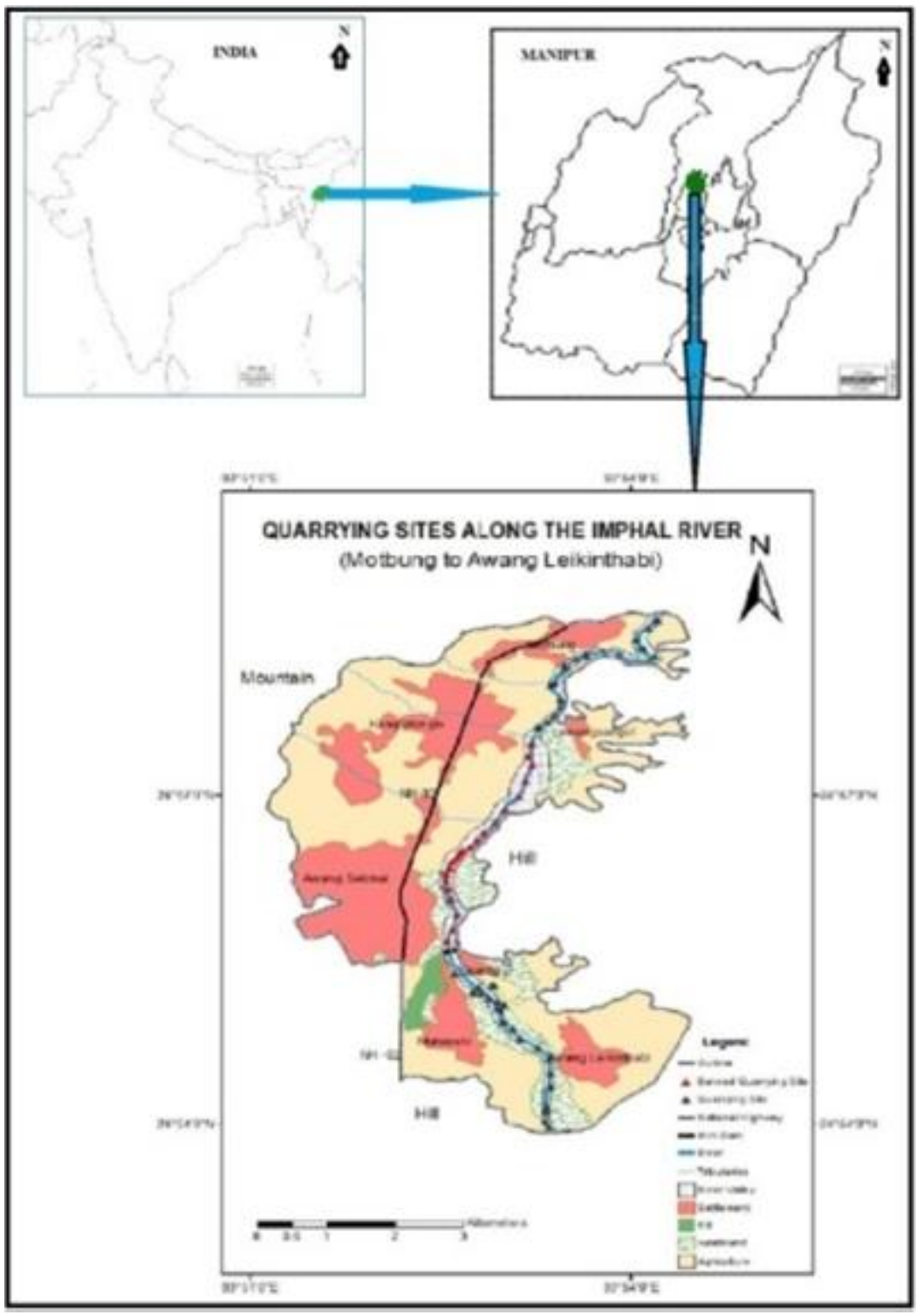

Fig 1: Location Map

\section{OBJective OF the Study}

- To identified the changes in the riverine landforms.

- $\quad$ To find out the environment problems related to quarrying activities.

\section{Material AND Methods}

The study is base on quantitative research designed involving direct field observation and interviews with the people to capture the information on sand and gravel extraction along the river. In order to understand the socioeconomic condition of the quarrying people, interview and informal discussion were conducting with the people at the quarrying sites along the river valley. To assess the landform changes and environmental impacts, satellite image of difference time interval had been use and analyzed in Remote Sensing and Geographical Information System (GIS) environment.

\section{SOCIO-ECONOMIC DePENDENCY}

In the world today, improved infrastructure and buildings indicate the sign of healthy living condition of the societies. In fact, development of infrastructure such as better transport, important government buildings, industries, etc. are very important for development of a region. Therefore, the basic amenities required for these infrastructural developments are mainly sand and gravel. Here lies the importance of sand and gravel quarrying activities. In the 
study area, the riverbed, floodplain and adjacent terrace of the Imphal River is a good source for extracting sand and gravel materials, which has been using for the construction of infrastructures. The extraction process along the Imphal River is carrying out by using shovel, sand strainer, mattock and pointed lever rode. Moreover, few numbers of excavators like land mover (JCB) are also being used for extracting sand and gravel from the riverbed.

Apart from using the extracted materials, quarrying is consider as a source of livelihood for many people because quarrying activities play a very important role in providing economy of the people. Many people get employed, more families have increased income and so on (Lawal P.O, 2011). The local people generally do quarrying activities in the study area. However, few migrant workers are engaged in quarrying activity. The local villages and the percentage of worker, which are engage in query in the study area, were listed as below.

Table 1: Percentage of workers from villages

\begin{tabular}{|c|c|c|}
\hline Sl. No. & Name of Village & Number of Workers in Percent \\
\hline 1 & Motbung & 17.15 \\
\hline 2 & Kanglatongbi & 1.91 \\
\hline 3 & Luwangsangol & 7.62 \\
\hline 4 & Awang Sekmai & 2.85 \\
\hline 5 & Maharabi & 44.76 \\
\hline 6 & Awang Leikinthabi & 18.09 \\
\hline 7 & Migrant & 7.62 \\
\hline
\end{tabular}

From the above table-1, it found that workers from Maharabi village account the highest. It constituted about 45 percent of the total worker in the study area. On the other hand, workers from Kanglatombi and Awang Sekmai constitute lowest i.e. 1.91 and $2.86 \%$ respectively. Migrant worker constituted about 7.62 percent of the total worker. Percentage distribution of worker engaged in the quarrying activity in the study region are $48 \%$ from Maharabi, $20 \%$ from Awang Leikinthabi, 19\% from Motbung, 8\% from Luwangsangol, 7.62\% from migrant, 3\% from Awang Sekmai and $2 \%$ from Kanglatongbi. Maharabi villages got the highest percentage of worker engaged in quarrying activities because they don't have any other source of income. On the other hand, numbers of people who are engaged in secondary and tertiary activities are very less.

\section{DISTRIBUTION OF WORKERS BY INCOME}

Literally, "Income" refers to "the money received for work". Therefore, the income of an individual can be the total sum of money received from his wages during a certain period. In order to examine the income level of workers per day, it classified into five-income level based on the collected data. The levels are - Rs. 100 - 200 per day, Rs. $200-400$ per day, Rs. 400 - 600 per day, Rs. 600 - 800 per day, Rs. 800 - 1000 per day, and the rate of income percentage are shown in the figure below.

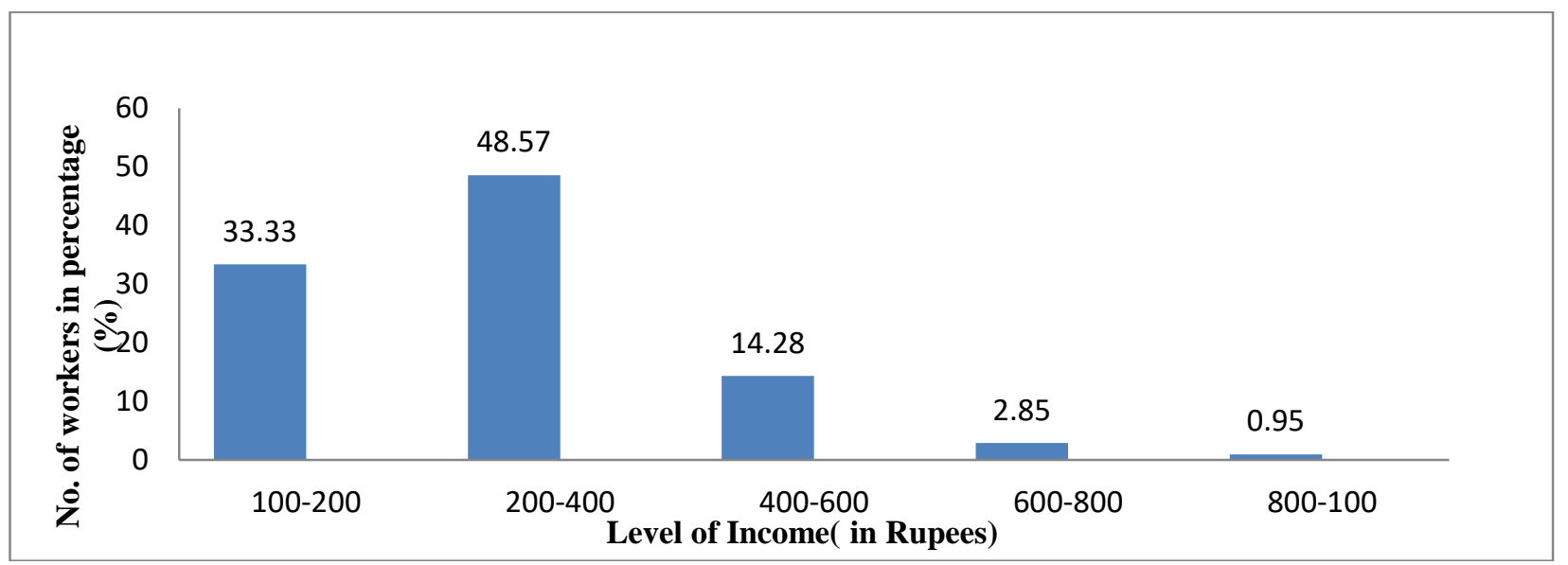

Fig 2: Income Structure of Worker

From the above figure, it found that most of the workers in the study area i.e. about $48.57 \%$ of the total worker earn at a range between rupees 200-400 per day. Only a small number of worker i.e. 0.95 percentage of the total worker earns between 800 - 1000 per month. This shows that most of the workers earned Rs.200-400 to support their family or livelihood. 
Here it is worth mentioning that most of the workers in the study area i.e. about $54 \%$ percent are unable to support their family with the income. The above figure will show the percentage of workers sufficient to manage their family with the daily income they get from quarrying activity.

\section{IMPACT OF QUARRYING ON RIVERINE LANDFORM AND ENVIRONMENT}

Although sand mining are expected to be regulated by law in many places, it is still many a times done illegally. It is rapidly becoming an ecological problem as the demand for sand increases in industry and construction (Whitehead, 2007). The environmental devaluation that is an aftermath of man's activities such as sand/gravel mining on land include disturbance of the landscape, ugly or distorted topography, agriculturally unproductive terrain, creation of pools of water for breeding pests, deforestation and general degrading of the ecosystem with air, land and water pollution (Lawal P.O, 2011). Quarrying activities along the Imphal River has provided a lot of benefit to the workers and to the people using the extracted materials. Nevertheless, it has negative impact to the physical environment of the river when large-scale extraction process of sand and gravel takes place from the river valley. Especially the surrounding people near the river feel the negative impacts on the physical environment. Therefore, a study needed to identify the negative impact on the environment. This article presents results and findings of a study on environmental impacts of sand and gravel quarrying along the Imphal River through observation and empirical information

According to the workers perception, during earlier times, sand and gravel were extracting from the riverbank that was brought down only by the running water during rainy season. The sediments like sand and gravel brought down were easily extracting without using any digging mechanism like the one pointed lever rode or mattock, as it is abundantly available on the riverbank surface. Since last few decades the rate of Imphal River discharge has decreased less intense and shortening the period of rainy days that ultimately reduces the sediment load carried by the river. On the other hand, with the increasing demand of sand and gravel (for construction work), its deposits were widely exploited during a short-term. This is because sand and gravel extraction process take place not only from the riverbank but also from the riverbed as well as from adjacent river terrace as deposition of sand and gravel has reduced. However, these short-term extraction processes cause long-term negative impact on the environment.

The present scenario of the physical structure of the river is drastically changed due to anthropogenic activities along the Imphal River. The removal of sand and gravel deposits from the river has direct effect on the physical environment of the river that leads to the negative impact. In fact, these environment degradations are the result of large-scale removal of river sediment and digging below existing riverbed. Such anthropogenic activity has altered the physical environment of the river in a very short duration. However, such a damaged will not be able to recover for a very long time. Hence, in order to understand the changes of river morphology, a comparative study of landform of 1970 and 2013 has been selected as an observe time interval.
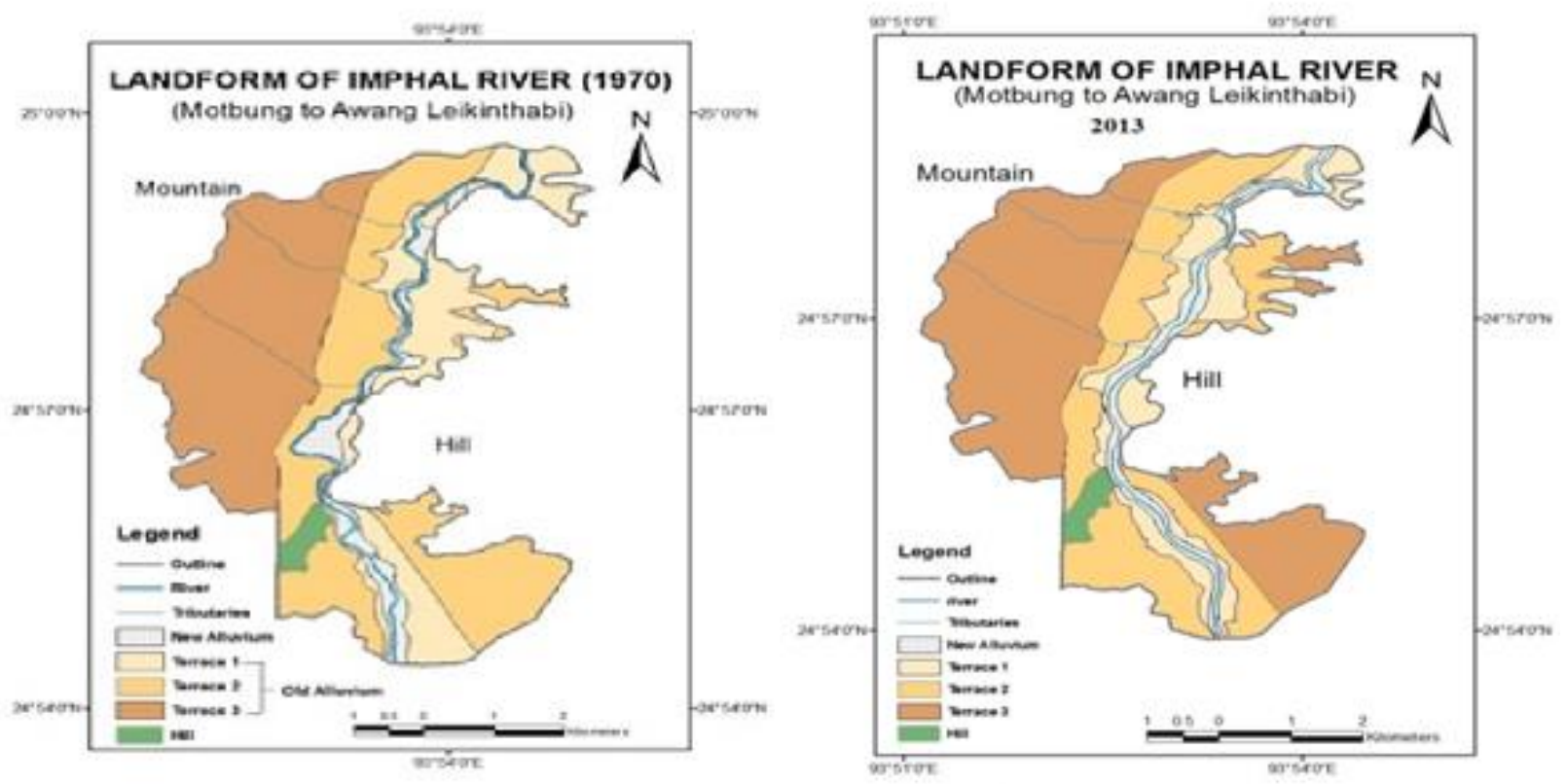

Fig 3: Landforms of the Imphal River 
Table 2: Landform Change from 1970 to 2013

\begin{tabular}{|c|l|l|l|l|}
\hline Sl. No. & Land form categories & 1970 & 2013 & Difference \\
\hline 1 & River & $13 \mathrm{~km}$ & $11 \mathrm{~km}$ & $-2 \mathrm{~km}$ \\
\hline 2 & Tributaries & $7.5 \mathrm{~km}$ & $8 \mathrm{~km}$ & $+.5 \mathrm{~km}$ \\
\hline 3 & New Alluvium or river valley & $2 \mathrm{sq} . \mathrm{km}$ & $2 \mathrm{sq} . \mathrm{km}$ & Nil \\
\hline 4 & Terrace 1 & 523 hectare & 351 hectare & -172 hectare \\
\hline 5 & Terrace 2 & 974 hectare & 747 hectare & -227 hectare \\
\hline 6 & Terrace 3 & 1047 hectare & 1250 hectare & +203 hectare \\
\hline
\end{tabular}

The changes of landform of the Imphal River from 1970 to 2013 have shown in the above fig-3 and table-2. In 1970, the course of the river flows meandering through the valley in a natural way but in 2013 the course of the river has straightened by cutting the menders. In 1970, the length of the river was $13 \mathrm{~km}$ and decreased its length to $11 \mathrm{~km}$ in 2013, that is shortening by $2 \mathrm{~km}$ and less point bar seen as the river has straightened.

Although there is, lot of changes is the location but by area, there is not much changes in the New Alluvium river valley. Terrace 1 in 1970 has 523 hectare and 351 hectares in 2013.The area has decrease by 172 hectare. Terrace 2 got 974 hectare in 1970 and 747 hectares in 2013, decreasing the terrace area by 227 hectares. Moreover, terrace 3 in 1970 has 1047 hectares and 1250 hectares in 2013, increasing the terrace area by 203 hectares. All these changes in the landform of Imphal River are mostly causing by anthropogenic activities rather than natural process.

Sand and gravel quarrying is causing a lot of environment damage. Direct extraction of gravel from rivers has been a common source of aggregate although adverse impacts on river stability is now well known (Dunne and Leopold, 1978). One of the major environment impact caused by quarrying is the changes in river course. Change in the flow of river is observing in many places due to illegal mining. In fact, excessive sand and gravel mining made the riverbed unstable. To meet the increasing demand of sand and gravel supplies, quarrying activities is widely done near riverbank. When sand and gravel from riverbank are extracting in large amount, the level of the riverbank is lower than the streambed. River tends to flow down at the lower level than higher level, and so the river flows down to the lower level leading to the changing of its course. Thus, the difference in level is one of the causes that change the river course. Another reason that cause in changing the river course is due to the debris left behind after finer or useful materials have been sorting out. Those piles of debris were left near the bank or in the middle of the river and it obstruct the smooth flow of the river diverting the original course of the river. Quarrying activities along the streambed also divert the course of the river when the riverbed is altering in order to extract sand and gravel to meet the increasing demand. Riverbed and adjacent areas were dug up in search of the materials to use in constructing purposes. Large deep pits were created while extracting sand and gravel deposits from the riverbank, streambed and from adjacent river terrace. These is because large scale extraction is done by using excavator machines like JCB to meet the increasing demand of the fast growing human population. These deep pits were dangerous to human and animals during the rainy season when flood occurs. During the flood, the deep pits created by quarrying activities were filling with water making it dangerous to cross the river. Man and animals trying to cross the river during the flood were drowned, as the location of deep pits cannot be identified. Thus, it leads to loss of life. Creating deep pits is also one of the major causes of negative impact on the physical environment of the river as well as to man and animal.

Large amount of sand and gravel are extracting within a short time without giving the river to recover the sediment deposit through natural process. Transported sediment is depositing along the river valley periodically through natural process. At the recent trend, the volume of water and occurrence of flood are decreases, as a result, sand and gravel deposits along the river valley are also decline, but the anthropogenic activities keeping on continuing without giving any important concern of the river. At the beginning when sand and gravel, deposits were abundantly found; it is extracted only from the riverbank. With the increasing demand of materials, extracting from all over the region leading to heavy erosion on the terraces during the monsoon time. Degradation of river channel is commonly observed when long term sediment extraction took place along the river channel. Sand and gravel were widely exploited from the river terrace leading to the reduction of sediment deposits. As the sediment deposits were reduced, extraction of sand and gravel were done even from the adjacent river terrace and from the inner layer of the terrace that lead to collapsing riverbank and ultimately widening and deepening of the riverbed

Apart from the changes is river system, sand and gravel mining causes a emend impact on agriculture, ground water as well as the water quality of downstream. Mining along the floodplain is done with an open pit mine or a quarry. These floodplain-mining activities may have several potential effects on the river system, including changes to the ecology, geomorphology, and hydrology (Mossa and Autin, 1997). Due to widening and deepening of river valley, lowering of the water level that leading to failure in irrigation system. As a result agricultural land on the terrace lack water and becomes a fallow land. 
Quarrying Activities alters not only the river bed, damage structure nearby the river and creating deep pits, but it also lower groundwater table leaving the well on the embankment of the Imphal River dry. 'Bed degradation from in stream mining lowers the elevation of stream flow and floodplain water table which in turn can eliminate water table-dependent woody vegetation in riparian areas, and decrease wetted periods in riparian wetlands.' These decreases in groundwater level affect the people living at the surrounding villages nearby the river. The people nearby the river used well as a source of drinking water. Therefore, when wells are dry up it leads to shortage of drinking water as well for domestic uses especially during the winter season.

Again, it examines how anthropogenic activity has caused significant changes in the quantity and quality of water within the river systems (Owens, P. N. et al., 2005). In-stream quarrying along the Imphal River gives negative impact upon the water quality of the river. Impacts include increased in short-term turbidity at the quarrying sites due to re-suspension of sediment, sedimentation due to stockpiling and dumping of excess quarrying materials, organic particulate matter from workers at the quarrying sites and oil leakage from excavation machinery and transportation vehicles like truck.

Increased bank erosion and collapsing riverbank increases suspended solids in the water at the quarrying sites and downstream. The suspended solids may adversely affect water users and aquatic ecosystems. The impact of water quality is particularly significant if water users downstream of the quarrying sites are abstracting water for domestic use. In addition, these will increase the cost of water treatment due to suspended particles. Oil leakage from transporting vehicles may pollute the water and the workers dispose waste materials

\section{CONCLUSION}

The present study identifies negative environmental impact of sand and gravel quarrying along the Imphal River where the resources are extracting for development purposes. The study on impact of sand and gravel quarrying along the Imphal River revealed both positive and negative effects. It highlighted both the positive and negative impact of sand and gravel quarrying through questionnaires and interviews with the workers and through observation.

The study also reveals that sand and gravel were extracted because of its importance as a resource and has many uses that include building infrastructures, plastering and making foundation. As a result, its demand increases and many people were engaged in quarrying activities. Workers consider quarrying activities as their source of income and their economic dependency on quarrying activities were revealed through questionnaire and interview. Sand and gravel quarrying are very important activities for economic development. However, quarrying disturbs river landform and excessive quarrying leads to depletion of resources on both riverbeds and adjacent agricultural land. The study discovered that the negative impact cause by the quarrying activities is increasing more at the ongoing quarrying sites than at the banned quarrying sites.

Quarrying activities gave both positive and negative impact, but negative impact given to the environment of the river is more than the positive impact given to the people. Positive impact given to the people by the quarrying activities is only for a short term but the negative impact given to the environment is in long-term. With the increase of urbanization and increasing population more infrastructure development are witnessing within the state that require large amount of building materials. As a result, more quarrying activities are practice within the study area. If such practices are not properly, control at proper time with proper planning, effects on environment will be increasing in the near future.

\section{REFERENCES}

Draggan S 2008: Encyclopedia of earth Sand and gravel. Washington D.C.

Dunne, T. and Leopold, L.B., 1978: Water in Environmental Planning, The Australian Littoral Society Inc. in association with the Queensland Museum; Brisbane, 295-302.

Langer, W.H. 2003: A general overview of the technology of in-stream mining of sand and gravel resources. Associated potential environmental impacts, and methods to control potential impacts, "USGS Open-File Report of-02-153

Lawal P.O., 2011: Effect of Sand/Gravel Mining in Minna Emirate Area of Nigeria on Stakeholders, Journal of Sustainable Development, vol 4, no. 1, pp 193-199

Madyise Tariro 2013: Case Studies of Environmental Impacts of Sand Mining and Gravel Extraction for Urban development in Gaborone, Phd thesis, University of South Africa.

Mossa, J., Autin, W.J., 1998: Geologic and geographic aspects of sand and gravel production in Louisiana. Aggregate Resources: A Global Perspective, 439-463

Owens, P. N. et al., 2005: Fine-grained sediment in river systems Environmental Significance and Management issues, River Research and Applications, no 21, pp 693-717

Stebbin M 2006: Can Gravel Mining and water Supply Wells co-exist. Maine: University of Maine.

The Ojos Negros Research Group, 2008: Sand mining facts. [Online] Available: http://threeissues.sdsu.edu/three_issues_sandminingfacts

Whitehead, G.J. 2007: Land and environment: sand mining. [Online] Available: $\quad$ http://localhistory.kingston.vic.gov.au/htu.

$$
--0 \text {-- }
$$

